\title{
EKSISTENSI BRAHMAVIHARA ARAMA SEBAGAI DESTINASI WISATA EDUKASI DAN SPIRITUAL DI DESA BANJAR TEGEHA, KECAMATAN BANJAR, KABUPATEN BULELENG
}

\author{
Putu Sabda Jayendra ${ }^{1}$, I Nyoman Sudiarta ${ }^{2}$ \\ ${ }^{12}$ Dosen Institut Pariwisata dan Bisnis Internasional \\ sabda@stpbi.ac.id
}

\begin{abstract}
ABSTRAK
Brahmavihara Arama yang berlokasi di Desa Banjar Tegeha, Kecamatan Banjar, Kabupaten Buleleng merupakan vihara Buddha terbesar di Bali. Vihara ini merupakan tempat suci yang diperuntukkan bagi umat Buddha yang didirikan sejak tahun 1969. Brahmavihara Arama merupakan salah satu destinasi wisata bernuansa religi, edukatif, dan spiritual yang banyak dikunjungi wisatawan mancanegara. Keberadaan vihara ini sangat unik dan menarik karena berada di tengah-tengah komunitas masyarakat Hindu Bali. Terlebih arsitektur vihara tersebut tidak sama dengan vihara yang bercorak kebudayaan Tiongkok, namun lebih dominan menggunakan arsitektur Bali. Fenomena ini tentu memiliki aspek historis dan filosofis yang sarat akan muatan edukatif. Fenomena lainnya adalah adanya aktivitas pelatihan meditasi yang melibatkan wisatawan mancanegara secara terstruktur yang terpusat di vihara ini. Hal tersebut menarik dan penting untuk dikaji lebih jauh. Tujuan penelitian ini untuk mengetahui materi edukasi yang disosialisasikan kepada wisatawan, serta aktivitas implementasi spiritualitas yang terjadi di Brahmavihara Arama. Penelitian ini mempergunakan Teori Interaksionisme Simbolik dan Teori Fungsionalisme Struktural dalam menganalisis permasalahannya. Hasil penelitian mengungkapkan bahwa aspek-aspek edukatif yang didapat wisatawan adalah toleransi (respect) dan filosofi pendakian spiritual melalui tahapan-tahapan dalam tiap struktur bangunan suci vihara yang dikunjungi. Sedangkan pola spiritualitas yang diterapkan pada wisatawan yang memang ingin mempelajari meditasi dilakukan secara bertahap. Tahap pertama adalah pengenalan ajaran Metta (kasih sayang universal), kemudian Samatha, yaitu melatih ketenangan melalui anapanasati, yaitu pengaturan napas. Setelah pengaturan napas dan posisi tubuh telah dikuasai barulah lanjut ke tahap Vipassana.
\end{abstract}

Kata Kunci : Arama, Wisata Edukatif, Wisata Spiritual.

\section{ABSTRACT}

Brahmavihara Arama is located in Banjar Tegeha Village, Banjar District, Buleleng Regency. It is the largest Buddhist temple in Bali. This temple is a sacred place for Buddhists established since 1969. Brahmavihara Arama is one of the religious, educational, and spiritual tourist destinations that are visited by many foreign tourists. The existence of this vihara is very unique and interesting because it is in the middle of Balinese Hindu community. Moreover, the architecture of the monastery is not the same as the vihara that has Chinese culture, but is more dominant in using Balinese architecture. This phenomenon certainly has historical and philosophical aspects that are loaded with educational content. Another phenomenon is the existence of meditation training activities 
involving foreign tourists in a structured manner centered in this monastery. It is interesting and important to be studied further. The purpose of this study are to define educational materials socialized to tourists, as well as spirituality implementation activities that occur in Brahmavihara Arama. This research uses Symbolic Interactionism Theory and Structural Functionalism Theory in analyzing the problem. The results revealed that the educational aspects that are got by the tourists, such as tolerance (respect) and philosophy of spiritual ascent through the stages in each structure of the sacred building of the monastery visited. While the pattern of spirituality applied to tourists who do want to learn meditation is done gradually. The first stage is the introduction of Metta (universal affection), then Samatha, which is to practice tranquility through anapanasati, namely the setting of breath. After the setting of the breath and position of the body has been mastered then continue to the stage Vipassana.

Keywords: Brahmavihara Arama, Educational Tourism, Spiritual Tourism

\section{PENDAHULUAN}

Pariwisata di Bali tidak terlepas dari keunikan religi dan budayanya yang khas. Dalam Peraturan Daerah Bali No. 3 Tahun 1974 yang telah diperbaharui menjadi Perda No. 3 Tahun 1991 dijelaskan; Kepariwisataan yang dikembangkan di Bali adalah "Pariwisata Budaya, satu jenis kepariwisataan yang bertumpu pada kebudayaan Bali yang dijiwai Agama Hindu. Dalam pasal 1 ditegaskan Pariwisata Budaya adalah jenis kepariwisataan yang dalam perkembangan dan pengembangannya menggunakan Kebudayaan Daerah Bali yang dijiwai oleh Agama Hindu yang merupakan bagian dari kebudayaan nasional sebagai potensi dasar yang dominan, yang di dalamnya tersirat satu cita-cita akan adanya hubungan timbal balik antara pariwisata dan kebudayaan sehingga keduanya meningkat secara serasi, selaras, dan seimbang (Jayendra, Sudarmawan, \& Wijaya, 2019:1-2). Berdasarkan pernyataan peraturan daerah tersebut, maka pariwisata yang cocok dikembangkan di Bali adalah yang lebih berbasis budaya.

Muljadi (2009:7) menyatakan bahwa pariwisata merupakan aktivitas pelayanan dan produk hasil industri pariwisata yang mampu menciptakan pengalaman perjalanan bagi wisatawan. Kodhyat (dalam Jayendra, 2019:1-2) menyatakan bahwa pada awal perkembangan pariwisata di dunia memang ditandai dengan aktivitas perjalanan atau petualangan seseorang ke tempat-tempat yang disenangi dengan berbagai tujuan, seperti melaksanakan ibadah agama, perdagangan, memenuhi rasa ingin tahu, tujuan rekreasi, melaksanakan suatu misi, atau tujuan edukatif. Artinya, para wisatawan yang berlibur bukan hanya sebatas bersenang-senang, namun yang terpenting adalah mendapatkan suatu pengalaman, pengetahuan, serta manfaat lebih dari perjalanan yang dilakukannya. Terlebih di Bali yang sistem religi berbalut budayanya yang sangat ikonik, sehingga mampu menarik minat wisatawan untuk memperoleh wawasan baru mengenai adat budaya yang berkembang di Bali.

Wisata alternatif yang sedang populer di kalangan pelaku pariwisata di Bali selain wisata edukatif adalah "Wisata Spiritual". Pariwisata spiritual adalah kegiatan yang dilakukan untuk menarik wisatawan dengan cara menawarkan produk-produk wisata yang berbau religius atau keagaman (Sukaatmadja, Wardana, Purbawangsa, \& Rahanatha, 2017:530). Wisata spiritual secara umum bertujuan untuk merasakan pengalaman-pengalaman spiritual serta merelaksasi kondisi 
psikologis. Potensi Bali untuk dikembangkan menjadi destinasi wisata spiritual sangat besar. Baru sekitar 5 persen dari jumlah total turis asing di Bali yang berwisata dengan tujuan memperoleh pengalaman spiritual (Pitana dalam Sutama, 2013:4). Destinasi wisata spiritual di Bali sesungguhnya sudah cukup banyak dan pada umumnya berlandaskan pada ritual-ritual keagamaan Hindu Bali. Namun ada pula destinasi wisata spiritual yang bercorak religi yang memiliki variasi keunikan tersendiri dan khas. Salah satunya adalah Brahmavihara Arama yang terletak di Desa Banjar Tegeha, Kecamatan Banjar, Kabupaten Buleleng.

Brahmavihara Arama merupakan vihara Buddha terbesar di Bali. Lokasinya di Desa Banjar Tegeha, Kecamatan Banjar, Kabupaten Buleleng, dan terletak di tengah-tengah pedesaan yang asri dan sejuk. Vihara ini memiliki keunikan yang menjadi ciri pembeda dengan vihara-vihara lainnya. Mayoritas vihara arsitekturnya bercorak kebudayaan Tiongkok, hampir menyerupai kelenteng milik Agama Konghuchu. Namun Brahmavihara Arama yang didirikan pada tahun 1969 ini sangat dominan berarsitektur Hindu Bali. Letak vihara inipun ada di tengah-tengah masyarakat yang mayoritas pemeluk Hindu. Bahkan para pengunjung lokal yang bersembahyang juga tidak hanya yang beragama Buddha saja, namun juga banyak diantaranya yang beragama Hindu. Hal ini menjadi suatu fenomena yang menarik interest para wisatawan asing yang berkunjung untuk mempelajari seluk-beluk keberadaan vihara ini lebih mendalam.

Keunikan lainnya adalah adanya aktivitas meditasi yang para pesertanya adalah para wisatawan mancanegara. Berdasarkan hasil observasi awal yang telah dilakukan, dapat diketahui bahwa kegiatan meditasi yang dilakukan bukanlah kegiatan yang bersifat spontanitas, namun sangat terstruktur dan sistematis, serta dilakukan secara periodik (terjadwal). Hal ini merupakan fenomena yang menarik untuk dikaji secara lebih mendalam. Terlebih di tengah anggapan banyak kalangan bahwa pariwisata spiritual yang terkesan menjual agama dan spiritualitas untuk kepentingan ekonomi, kegiatan pariwisata edukasi dan spiritual yang dilakukan di Brahmavihara Arama justru dimaksudkan untuk bentuk revitalisasi toleransi lintas agama dan lintas budaya. Selain itu, aktivitas penyembuhan psikologis wisatawan yang mengalami stress melalui meditasi dimaknai sebagai suatu bentuk keihklasan dalam berkarma, tolong-menolong, dan tindakan berpahala. Dalam hal ini, wisatawan dipandang perlu diedukasi melalui partisipasi langsung dalam tindakantindakan spiritualitas yang terpola. Implikasi yang diharapkan secara hakikat lebih pada pembentukan karakter religius yang meliputi pemahaman yang mendalam dan respect terhadap spiritualitas dan religiusitas masyarakat Bali dalam berbagai perspektif lintas agama. Pemahaman semacam ini dipandang perlu diberikan di Brahmavihara Arama untuk mengubah persepsi mayoritas wisatawan agar tidak lagi memandang budaya Bali sebagai sesuatu yang kaku dan dogmatis. Dengan demikian, para wisatawan mendapatkan suatu gambaran yang utuh berkenaan dengan kebudayaan Bali yang fleksibel dan religius, namun tetap mampu menaungi perbedaan keyakinan beragama.

Berpijak pada hal tersebut, maka penelitian yang mengambil tema "Eksistensi Brahmavihara Arama Sebagai Destinasi Wisata Edukasi dan Spiritual di Desa Banjar Tegeha, Kecamatan Banjar, Kabupaten Buleleng” bertujuan untuk mengetahui materi edukasi yang disosialisasikan kepada wisatawan, serta aktivitas implementasi spiritualitas yang terjadi di Brahmavihara Arama. Melalui penelitian ini, diharapkan diperoleh pemahaman yang utuh dan mendalam akan hakikat tujuan 
pariwisata spiritual yang hakiki, serta dapat menjadi referensi yang memberikan gambaran terkait pengembangan destinasi wisata spiritual lainnya.

\section{METODE PENELITIAN}

Lokasi penelitian ini adalah Brahmavihara Arama yang terletak di Desa Banjar Tehega, Kecamatan Banjar, Kabupaten Buleleng. Vihara ini dikenal pula dengan nama Vihara Buddha Banjar. Lokasi ini berjarak 83,7 km dari kota Denpasar sebagai pusat pemerintahan Provinsi Bali dan 19,6 km dari kota Singaraja sebagai pusat pemerintahan Kabupaten Buleleng. Untuk memudahkan memetakan lokasi penelitian, dapat dilihat pada gambar berikut. Alasan pemilihan lokasi ini, disamping merupakan Vihara terbesar di Bali, juga karena adanya aktivitas wisata edukatif dan spiritual, serta melibatkan para wisatawan dan mancanegara. Aktivitas wisata edukatif dan spiritual yang terjadi di lokasi ini merupakan aktivitas yang terstruktur dan sistematis, serta terjadwal secara rutin. Dengan demikian, penting dan menarik untuk dikaji akan adanya fenomena tersebut secara lebih mendalam.

Penelitian ini merupakan penelitian kualitatif, karena data yang diperoleh dalam penelitian ini tidak dicapai melalui prosedur statistik atau dengan cara kuantifikasi lainnya. Penelitian kualitatif berfokus pada fenomena sosial dan pada pemberian suara pada perasaan dan persepsi dari partisipan di bawah studi (Emzir, 2010:2). Penelitian ini mempergunakan pendekatan sosial humaniora. Pendekatan sosial humaniora dipergunakan mengungkap aktivitas wisata edukasi dan wisata spiritual yang terjadi di Brahmavihara Arama di Desa Banjar Tegeha, Buleleng. Informan dalam penelitian ini dipilih dengan teknik purposive. Dalam hal ini setiap informan yang dihubungi disesuaikan dengan kriteria-kriteria tertentu yang diterapkan berdasarkan tujuan penelitian.Beberapa kriteria yang ditetapkan di antaranya yakni melihat dari hubungan antara variabel permasalahan yang diteliti dengan latar belakang informan tersebut, seperti pihak pengelola Brahmavihara Arama, tokoh-tokoh agama (bhikku) dan wisatawan. Dengan demikian diharapkan peneliti dapat memperoleh informasi yang menyeluruh terkait dengan tema penelitian dibahas.

Penumpulan data dilakukan dengan observasi non-partisipan, wawancara berstruktur, dan studi kepustakaan. Teknik analisis data dalam penelitian ini adalah deskriptif kualitatif, karena data-data dalam penelitian ini tidak berupa angka. Teknik deskriptif kualitatif adalah menafsirkan suatu gejala objektif sesuai dengan data kepustakaan maupun data lapangan yang menjadi objek penelitian. Adapun langkah-langkah yang dipergunakan dalam analisis data penelitian ini adalah reduksi, penyajian dan penarikan kesimpulan. Mereduksi data dilaksanakan dengan merangkum atau membuat ringkasan, menelusuri masalah, membuat satuan-satuan data yang lebih kecil sesuai dengan masalah yang dikaji. Satuan-satuan yang dibuat kemudian diberi kode untuk memudahkan pemaparan data. Selama proses pengumpulan data, peneliti melakukan kegiatan menyeleksi, atau memilah-milah hasil observasi dan wawancara serta memusatkan perhatian sesuai dengan tema penelitian. Langkah kedua dalam proses analisis data yaitu penyajian data. Menurut Miles dan Huberman (dalam Darmawati, 2010:53) menyatakan bahwa penyajian data merupakan proses penyajian sekumpulan informasi yang kompleks ke dalam bentuk yang sederhana dan selektif sehingga mudah dipahami maknanya. Penyajian data merupakan bagian dari analisis untuk merangkai atau menyusun informasi yang memberi kemungkinan adanya penarikan kesimpulan dan mengambil 
tindakan. Langkah ketiga dalam aktivitas analisis data adalah penarikan kesimpulan. Emzir (2010:133) menyatakan bahwa dari permulaan pengumpulan data, peneliti kualitatif mulai memutuskan apakah makna sesuatu, mencatat polapola, penjelasan, konfigurasi yang mungkin, alur kausal, dan proposisi-proposisi. Setelah mencermati hasil maka kegiatan penelitian ditutup dengan menarik suatu kesimpulan.

\section{HASIL DAN DISKUSI}

\section{ASPEK-ASPEK EDUKATIF YANG DIBERIKAN PADA WISATAWAN}

Vihara pada persepsi kebanyakan orang merupakan tempat suci bagi umat Buddha. Namun pada Brahmavihara Arama yang merupakan vihara terbesar di Bali tidak hanya murni bercorak Buddha, melainkan ada pula corak-corak Hindu yang masuk dan menjadi satu kesatuan akulturasi budaya yang khas. Dari segi ajaran spiritualitas yang disosialisasikan pun memiliki banyak kesamaan dengan ajaran Hindu, terutama karena Buddha sendiri awalnya secara original merupakan cabang filsafat yang dikonstruksi dari Hindu. Hal ini menjadi daya tarik tersendiri, khususnya para wisatawan berkunjung ke vihara ini. Wisatawan yang datang ke vihara ini tidak hanya menjadi penikmat, namun mendapatkan manfaat-manfaat yang bersifat edukatif. Adapun aspek-aspek edukatif yang diberikan pada wisatawan adalah berupa pemahaman-pemahaman sebagai berikut.

1. Toleransi (Respect)

Istilah toleransi dalam bahasa Inggris tolerance berarti sikap membiarkan, mengakui, dan menghormati keyakinan orang lain tanpa memerlukan persetujuan (Bahari, 2010:50). Dalam Webster's World Dictionary of American Language, dinyatakan bahwa toleransi berasal dari bahasa Latin "tolerare" yang berarti menahan, menanggung, membetahkan, membiarkan, dan tabah (Bahari, 2010:50). Pada tahun 1995, UNESCO mengeluarkan deklarasi tentang prinsip-prinsip toleransi yang salah satunya berbunyi "Toleransi adalah penghargaan, penerimaan, dan penghormatan terhadap kepelbagaian cara-cara kemanusiaan, bentuk-bentuk ekspresi dan kebudayaan" (Baghi, 2012:40). Jayendra (2014) menyatakan bahwa pada hakikatnya, sikap toleransi merupakan suatu sikap menghormati, saling mengerti, saling menghargai dan menerima berbagai bentuk perbedaan orang atau komunitas lain, baik dalam hal agama, kepercayaan, budaya, maupun cara-cara hidup lainnya.

Pemahaman tentang toleransi merupakan salah satu aspek edukatif yang diperoleh oleh para wisatawan yang berkunjung ke Brahmavihara Arama. Tentunya manfaat edukatif ini didapatkan melalui menyaksikan langsung dan melakukan langsung, yaitu diperbolehkannya wisatawan melihat-lihat bahkan melakukan penghormatan terhadap Sang Buddha. Para wisatawan yang datang tentunya berasal dari berbagai kalangan agama, domestik, maupun mancanegara. Mayoritas dari wisatawan tersebut adalah nonBuddha, namun dengan kesadaran sendiri tetap memberikan respectnya pada simbol-simbol Buddha sebagaimana ditunjukkan dalam gambar berikut. 


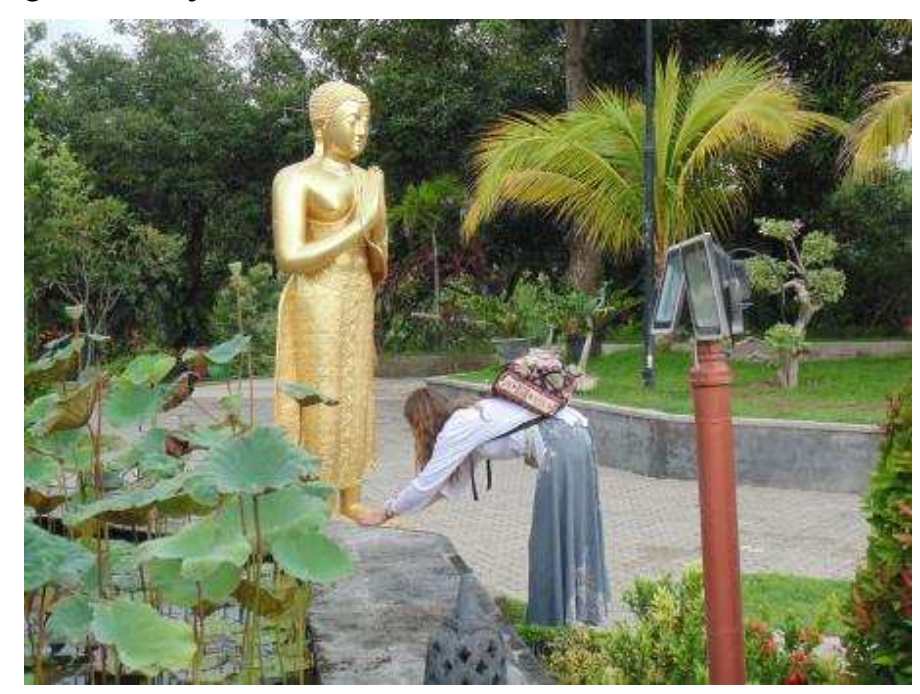

Gambar 1 Wisatawan Mancanegara Yang Memberi Penghormatan Pada Sang Buddha (Dok. Jayendra, 2020)

Dapat disimpulkan bahwa toleransi diaplikasikan para wisatawan dengan memberikan respect pada cara-cara keyakinan agama lain, dalam hal ini adalah Buddha. Prinsip-prinsip ini dijunjung tinggi karena dalam esensi keyakinan Buddha sendiri toleransi merupakan perwujudan dari cinta dan kasih sayang (Metta), sebagai salah satu syarat terciptanya kedamaian.

2. Pemahaman Mengenai Fungsi Tiap Bangunan Suci

Brahmavihara Arama yang memiliki luas total kurang lebih 4 hektare terdiri dari beberapa bangunan suci dengan fungsi yang berlainan. Areal vihara ini bertingkat-tingkat dengan setiap tingkatannya memiliki satu atau beberapa bangunan suci. Para wisatawan yang datang dan ingin melakukan penghormatan pada Sang Buddha diajak untuk melakukannya dari tingkatan terbawah, dengan memasuki tiap bangunan suci yang ada, sampai pada tingkatan tertinggi. Dengan kata lain, hal ini ibarat menjalankan filosofi pendakian spiritual dari tingkatan terbawah hingga sampai pada tingkatan puncak.

Untuk mengedukasi wisatawan, maka di depan setiap bangunan suci sudah tersedia papan yang memuat petunjuk, sejarah, serta fungsi bangunan suci yang akan dimasuki. Begitupula saat sudah memasuki bangunan tersebut, para wisatawan mendapat penjelasan dari guide yang sudah memahami tentang seluk-beluk Brahmavihara Arama. Hal tersebut dapat dilihat dalam gambar-gambar berikut. 


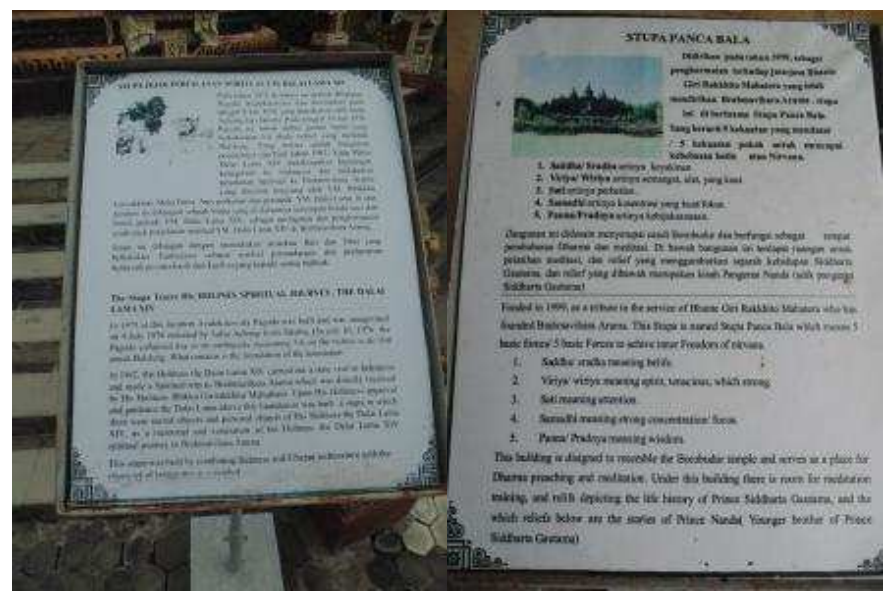

Gambar 2 Papan Penjelasan Tentang Sejarah dan Fungsi Tiap Bangunan Suci (Dok. Jayendra, 2020)

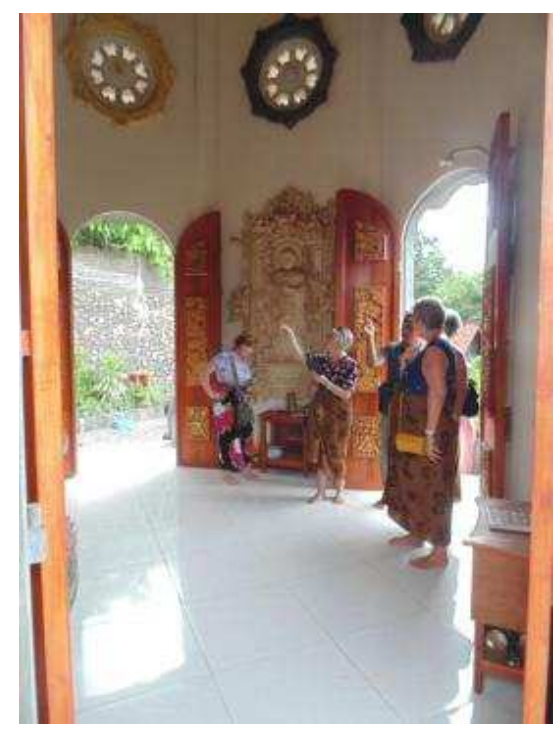

Gambar 3 Wisatawan Mendapat Penjelasan Guide

(Dok. Jayendra, 2020)

Melalui kegiatan ini, secara langsung dan tidak langsung, pemahaman wisatawan akan hakikat tingkatan spiritual akan terkonstruksi. Dalam menuju kedamaian dan pencerahan yang sejati, prosesnya tidaklah mudah. Secara fisik ada kelelahan yang dirasakan. Begitu pula secara mental (batin), ada ketidaksabaran yang cenderung dialami oleh wisatawan, namun pengertian yang terus menerus diberikan bahwa hal-hal semacam itulah yang harus dikekang dan dikendalikan. Melalui pengertian tersebut, para wisatawan akhirnya dengan kesadaran sendiri mengikuti alurnya step by step sampai pada puncak bangunan suci tertinggi, yaitu Stupa Panca Bala. Apabila sudah berhasil mencapai areal bangunan suci ini maka pendakian spiritualpun dapat dikatakan berhasil, meskipun dalam kasus ini hanya sebatas simulasi.

Perlu diketahui bahwa wisatawan yang melakukan kegiatan ini adalah pengunjung biasa dan bukan wisatawan yang intens mengikuti kelas 
meditasi. Meskipun hanya pengunjung biasa, namun diwajibkan mengikuti regulasi yang ada, yaitu tingkat demi tingkat. Sampai sejauh ini dalam pengamatan peneliti, wisatawan tidak langsung diarahkan menuju areal suci yang utama, melainkan dari tingkat yang terbawah. Dengan demikian, diharapkan proses tingkatan spiritual dalam perspektif filsafat Buddha akan dapat dipahami oleh wisatawan.

\section{POLA SPIRITUALITAS YANG DITERAPKAN PADA WISATAWAN}

Pola spiritualitas yang diterapkan pada wisatawan dalam hal ini merupakan tahapan-tahapan yang diimplementasikan pada wisatawan yang serius ingin menekuni spiritualitas. Wisatawan yang ingin menekuni spiritualitas ini beranjak dari motivasi yang berbeda-beda. Menurut hasil wawancara dengan informan, beberapa motivasi yang melatarbelakangi wisatawan untuk menekuni spiritualitas di Brahmavihara Arama adalah:

1. Sekedar ingin tahu. Pada dasarnya wisatawan yang termasuk dalam kategori ini adalah yang sama sekali belum pernah bersentuhan dengan dunia spiritual. Awalnya tertarik mengikuti meditasi sekedar ingin tahu dan merasakan sensasinya karena mendengar dari berbagai sumber, termasuk media sosial bahwa ada kegiatan berbasis spiritual yang diterapkan di Brahmavihara Arama.

2. Ingin mengatasi stress akibat berbagai permasalahan hidup. Wisatawan yang termasuk dalam kategori ini biasanya beranjak dari permasalahanpermasalahan atau berbagai tekanan yang dialami dalam rutinitas kesehariannya. Jalan spiritualitas melalui yoga dan/atau meditasi menjadi alternatif yang dipandang cocok untuk meringankan beban hidupnya.

3. Ingin serius mendalami jalan spiritual. Wisatawan kategori ini memang memiliki niatan yang sungguh-sungguh ingin menekuni spiritualitas. Kategori ini masih dibagi lagi dalam dua sub kelompok kategori, yakni; a) Wisatawan kelompok pemula, yang betul-betul baru belajar, dan b) Wisatawan yang sudah berpengalaman, dalam arti wisatawan itu sudah pernah belajar tentang spiritualitas di tempat lain, namun ingin membandingkan (studi banding) ke Brahmavihara Arama untuk mendapatkan pengalaman yang berbeda.

Wisatawan yang mengikuti kelas meditasi disediakan tempat menginap yang menjadi satu areal dengan vihara, atau juga bisa menyewa tempat penginapan pribadi (hotel atau homestay) yang relatif dekat dengan lokasi vihara. Hal ini dikarenakan untuk kelas meditasi tidak hanya sekali dilaksanakan. Minimal 3 kali pertemuan sampai 15 kali pertemuan. Satui sesi pertemuan berkisar sampai 3 jam. Bahkan wisatawan yang sudah merasa menemukan kenyamanan batin dengan kesadaran sendiri bisa mengikuti lebih dari 15 sesi pertemuan, atau saat berlibur kembali ke Bali akan kembali menuju Brahmavihara Arama untuk lanjut memperdalam pemahaman spiritualitasnya. Pola-pola implementasi spiritualitas yang diterapkan pada wisatawan tercermin dari tahapan-tahapan yang diberikan, yaitu sebagai berikut.

1. Metta

Metta berarti cinta kasih universal, cinta kasih semesta yang tidak mengenal batas cakrawala bagi semua. Menurut ajaran Buddha Gautama, inilah cinta kasih sejati yang melimpah dari Yang Maha Pengasih dan Penyayang 
(Zulkifli, 2016:193). Metta adalah pemahaman yang paling pertama diberikan bagi wisatawan, terutama yang baru menyelami dunia spiritualitas. Pada tahapan ini, belum dilakukan posisi meditasi dengan sikap tubuh, namun masih berupa doktrin.

Konsepsi Metta mirip dengan ajaran Tattwam Asi dalam spiritualitas Hindu. Metta pada dasarnya merupakan kasih sayang universal, tidak saja kepada sesama manusia, melainkan kepada semua makhluk di alam. Penerapan konsep ini dilakukan dengan mengajak wisatawan belajar teori, dan praktiknya dilakukan dengan mengheningkan diri dan hati terlebih dahulu. Praktik teori mengenai ajaran cinta kasih universal dilakukan secara terpusat, dengan bimbingan dari seorang Bikkhu sebagaimana tampak dalam gambar berikut.

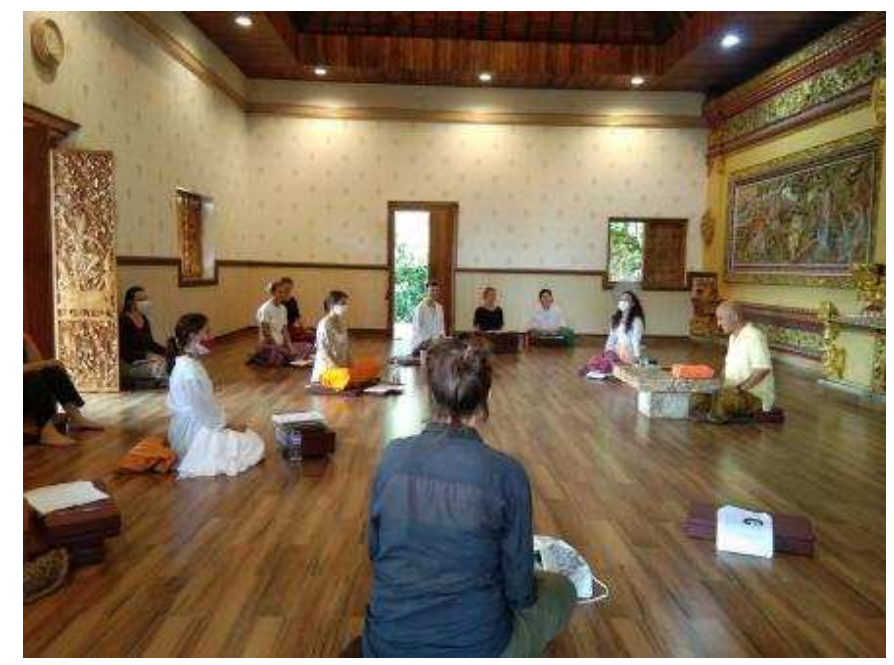

Gambar 4 Wisatawan Yang Mempelajari Konsep Cinta Kasih Universal Dibawah Bimbingan Seorang Bikkhu (Dok. Jayendra, 2020)

Secara praktik meditasinya, tahap ini tidak mementingkan posisi tubuh, hanya terbatas pada meditasi ringan. Artinya wisatawan diijinkan untuk mengambil posisi tubuh senyaman mungkin, dan lebih berorientasi pada penyatuan antara dirinya dengan alam sekelilingnya. Pikiran diijinkan untuk melayang bebas menyatu dengan suara-suara alam di sekelilingnya, sekaligus melebur atau melepaskan segala beban pikiran, stress, serta melupakan hal-hal yang menjadi masalah hidup lainnya. Dengan demikian tujuan akhirnya akan tumbuh rasa kasih sayang pada semesta dan kesadaran bahwa antara diri sendiri dengan alam sekelilingnya adalah satu bagian yang tidak terpisahkan.

2. Samatha

Kata Samatha (bahasa Pali) berarti "ketentraman" atau "ketenangan" yang memantapkan, menyusun, menyatukan dan memusatkan pikiran (Wijoyo \& Surya, 2017:124). Samatha (ketenangan) dianggap sebagai prasyarat konsentrasi. Dalam praktik meditasi, Samatha mengacu pada teknik yang membantu dalam menenangkan pikiran. Untuk mencapai ketenangan dan pikiran yang terpusat, Samatha dilakukan dengan Anapanasati. Anapanasati merupakan teknik konsentrasi tahap pertama memalui 
pengaturan napas. Dalam hal ini wisatawan yang sudah sampai pada tahapan samatha, diarahkan untuk melakukan Anapanasati, yaitu teknik pernapasan.

Pernapasan yang dilakukan bukanlah bernafas seperti biasanya, melainkan pernapasan yang terkonsentrasi. Tekniknya sesuai dengan esensi dari istilah Anapanasati itu sendiri, yaitu terfokus kepada napas ketika menghirup udara masuk dan menghembuskan udara keluar. Ana atau Adsasah artinya bernapas masuk (breathing in), Apan atau Passanah artinya bernapas keluar (breathing out), Sati artinya ingatan saat ini (mindfulness). Maka, Anapanasati artinya ingatan menarik napas masuk dan keluar saat ini(mindfullness of breathing in and out dalam Pantham, 2019:21).

Pengaturan nafas yang stabil merupakan syarat utama untuk merelaksasi pikiran. Para wisatawan yang baru kali pertama mempelajari Anapanasati diinstruksikan untuk mengatur sikap duduk dengan bersila, posisi badan tegak, dan jika kurang nyaman masih diperbolehkan untuk bersandar, serta tangan mengambil sikap meditasi Buddha. Instruksi selanjutnya yaitu menarik napas perlahan sepanjang mungkin, lalu menahan napas beberapa saat, dan menghembuskannya perlahan, tidak boleh tergesa-gesa.

Banyak wisatawan yang baru pertama mencoba teknik ini, meskipun kelihatannya mudah, namun ternyata cukup sulit. Biasanya Anapanasati dianggap belum berhasil jika tarikan dan hembusan napas belum berirama secara teratur. Apalagi saat menahan tidak bisa terlalu lama dan saat menghembuskan napas terjadi batuk-batuk, harus terus dicoba hingga lebih baik dari sebelumnya. Tahap ini relatif lama dipelajari, karena persyaratannya memang menuntut napas menjadi lebih teratur dari sebelumnya.

Apabila pengaturan napas sudah menjadi lebih teratur, barulah tahap berikutnya mengarahkan pikiran ke bagian tubuh yang terkena aliran napas. Perlahan-lahan mencoba memfokuskan pikiran dan membuang segala beban pikiran melalui setiap hembusan napas. Langkah ini diupayakan secara natural agar ketenangan pikiran perlahan-lahan dapat tercapai, sehingga jika kondisi wisatawan yang awalnya penuh dengan beban pikiran, dalam tahap ini mulai dikurangi dan disembuhkan sampai pada pencapaian kondisi samatha (ketenangan rohani).

3. Vipassana

Vipassana merupakan tahap akhir dari teknik meditasi yang diajarkan pada wisatawan yang mengikuti meditasi. Teknik vipassana, yang berarti melihat segala sesuatu sebagaimana adanya, adalah salah satu teknik meditasi yang paling kuno dari India. Dalam bahasa India pada masa sang Buddha, passanā berarti melihat dengan mata terbuka, dengan cara yang biasa, tetapi Vipassana adalah mengamati segala sesuatu seperti apa sesungguhnya mereka, bukan hanya seperti apa yang terlihat (Adriansyah, Saputri, Lawolo, \& Arsha, 2018:51-52). Hal ini erat kaitannya dengan filsafat "berisi adalah kosong, kosong adalah berisi”, yang artinya manusia diajarkan untuk tidak terikat pada bentuk fisik suatu objek, melainkan memahami serta berusaha melepaskan segala ikatan-ikatan yang membuat adanya penderitaan akibat ketertarikan pada objek tersebut. 
Meditasi Vipassana mengarah kepada pencapaian spiritual yaitu pembebasan dan pencerahan. Tujuannya sama sekali bukan untuk menyembuhkan penyakit jasmani. Akan tetapi, sebagai efek dari permurnian pikiran, banyak penyakit psikosomatik yang disembuhkan. Sesungguhnya Vipassana menghapus ketiga penyebab dari ketidakbahagiaan: nafsu keinginan, kebencian dan kebodohan batin. Dengan praktek yang berkesinambungan, meditasi ini akan melepaskan ketegangan-ketegangan yang muncul di dalam kehidupan sehari-hari, membuka simpul-simpul yang dibentuk dari kebiasaan lama yang bereaksi terhadap situasi yang menyenangkan maupun yang tidak menyenangkan dengan cara yang tidak seimbang. Adakalanya dalam mempelajari Vipassana, tidak terbatas di ruangan, namun membaur dengan alam di sekeliling vihara untuk merasakan sensasi penyatuan antara jiwa raga manusia dengan alam sekitarnya sebagaimana tampak dalam gambar berikut.

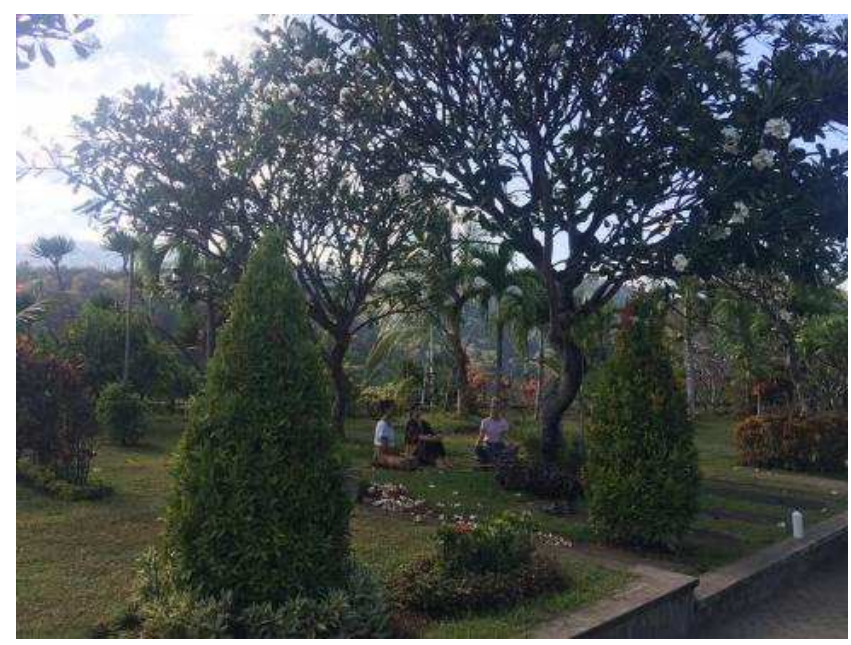

Gambar 5 Wisatawan Yang Bermeditasi Di Tengah-Tengah Alam Sekitar Vihara (Dok. Jayendra, 2020)

Sikap duduk yang dilakukan adalah dengan badan tegak namun santai, mata terpejam dan tangan diletakkan secara lurus di atas lutut yang bersila. Ujung jari telunjuk dipersatukan dengan ujung ibu jari. Sesungguhnya Vipassana tidak hanya posisi duduk, melainkan adakalanya juga berbaring, namun posisi duduk bersila sebagaimana yang telah dijabarkan di atas adalah sikap yang paling sering dilakukan karena bermanfaat terhadap kesehatan.

Dalam meditasi Vipassana, penekanan materinya berupa satipatthana atau perenungan yang terdiri dari empat macam perenungan yaitu:

1. Kāyanupassana (perenungan terhadap badan jasmani). Dalam perenungan ini, peserta meditasi diarahkan untuk memahami apa sesungguhnya yang dibutuhkan oleh badan jasmani, tidak memanjakan indriya dan melakukan pengendalian diri terhadap keinginan-keinginan pemuas jasmaniah.

2. Vedanānupassana (perenungan terhadap perasaan). Terdapat tiga macam yaitu: perasaan menyenangkan (sukha vedanā), perasaan tidak menyenangkan (dukha vedanā), dan perasaan netral (upekkhā vedanā). Dalam hal ini peserta diarahkan merenungkan perasaan yang sedang dialami 
secara objektif. Perasaan senang, dan tidak senang direnungkan bagaimana ia timbul, berlangsung, dan kemudian lenyap. Apabila perasaan telah dapat diatasi dengan cepat, maka batin menjadi bebas dan tidak terikat apapun.

3. Cittanupassana (perenungan terhadap kesadaran). Cittanupassana berarti perhatian penuh pada kesadaran (citta) dan bentuk-bentuk mental (cetasika) yang muncul bersama dengan kesadaran. Setiap pikiran terdiri dari faktorfaktor mental dan hal yang berhubungan dengan kesadaran itu sendiri. Kesadaran tidak pernah timbul sendiri, tapi muncul bersama dengan hal yang berhubungan dengannya. Dalam hal ini peserta diarahkan untuk merenungi dan menyadari, serta menginstrospeksi diri. Contohnya apabila manusia diliputi kemarahan, sedapat mungkin menyadari dirinya sedang diliputi kemarahan dan pikiran logisnya mengarahkan untuk meninggalkan kemarahan itu.

4. Dhammanupassana (perenungan terhadap bentuk-bentuk pikiran). Adalah perenungan terkait bentuk-bentuk pikiran dengan melihatnya dari dalam dan luar secara bergantian sehingga mengetahui hal-hal yang menimbulkan dan melenyapkan bentuk-bentuk pikiran tersebut. Pikiran akan ke-aku-an (sombong) akibat keterikatan pada objek atau gelar (prestise), keterikatan pikiran akan identitas, dan lain sebagainya diupayakan untuk dilenyapkan.

Dapat disimpulkan bahwa melalui empat macam perenungan ini, meditasi yang diimplementasikan pada peserta lebih banyak berorientasi pada pembentukan kesadaran dan pengendalian diri serta pikiran. Dengan melalui tahapan-tahapan tersebut, diharapkan wisata spiritual yang dilakukan dapat bermanfaat untuk mengatasi segala permasalahan hidup dan beban-beban akibat keterikatan indriya dapat disembuhkan.

\section{SIMPULAN}

Berdasarkan pembahasan sebelumnya, maka dapat disimpulkan bahwa aspek-aspek edukatif yang diberikan kepada wisatawan yang berkunjung ke Brahmavihara Arama berupa toleransi (respect), yaitu dengan diijinkannya umat lain untuk datang dan memberikan penghormatan kepada Sang Buddha. Aspek edukatif lainnya adalah pemahaman mengenai filosofi pendakian spiritual, yaitu wisatawan yang datang dan ingin melakukan penghormatan pada Sang Buddha diajak untuk melakukannya dari tingkatan terbawah, dengan memasuki tiap bangunan suci yang ada, sampai pada tingkatan tertinggi. Pola spiritualitas yang diterapkan pada wisatawan yang memang ingin mempelajari meditasi dikakukan secara bertahap. Tahap pertama adalah pengenalan ajaran Metta (kasih sayang universal), kemudian Samatha, yaitu melatih ketenangan melalui anapanasati, yaitu pengaturan napas. Setelah pengaturan napas dan posisi tubuh telah dikuasai barulah lanjut ke tahap Vipassana, yang penekanan materinya berupa satipatthana atau perenungan yang terdiri dari empat macam perenungan yaitu: (1) Kāyanupassana (perenungan terhadap badan jasmani), (2) Vedanānupassana (perenungan terhadap perasaan), (3) Cittanupassana (perenungan terhadap kesadaran), dan (4) Dhammanupassana (perenungan terhadap bentuk-bentuk pikiran).

Adapun saran-saran yang dapat diberikan sebagai penutup dalam penelitian ini adalah hendaknya kegiatan wisata spiritual dengan pola-pola meditasi dapat terus dikembangkan secara intensif sehingga perjalanan wisata yang dilakukan 
tidak saja sekedar bermanfaat untuk belajar, namun juga mampu memaknai tujuan hidup yang hakiki, serta berdampingan secara harmonis antara sesama manusia dan alam sekitarnya.

\section{DAFTAR PUSTAKA}

Adriansyah, M. A., Saputri, A., Lawolo, A. N., \& Arsha, J. S. (2018). Vipassana Sebagai Upaya Preventif Bagi Penderita Fear Of Missing Out (FoMo). Psikostudia: Jurnal Psikologi, 7(1), 50-59.

Baghi, F. (2012). Pluralisme, Demokrasi dan Toleransi. Yogyakarta: Ledalero.

Bahari, H. (2010). Toleransi Beragama Mahasiswa (Studi tentang Pengaruh Kepribadian, Keterlibatan Organisasi, Hasil Belajar Pendidikan Agama, dan Lingkungan Pendidikan terhadap Toleransi Mahasiswa Berbeda Agama pada 7 Perguruan Tinggi Umum Negeri). Jakarta: Badan Litbang dan Diklat Puslitbang Kehidupan Keagamaan.

Darmawati, I. A. N. (2010). Upacara Ngusaba Nangkan di Desa Pakraman Penglipuran, Kelurahan Kubu, Kabupaten Bangli (Perspektif Pendidikan Agama Hindu). Tesis. Program Pascasarjana IHDN Denpasar.

Emzir. (2010). Metodologi Penelitian Kualitatif Analisis Data. Jakarta: Raja Grafindo Persada.

Jayendra, P. S. (2014). Pengantar Perkuliahan Agama. Denpasar: STPBI.

Jayendra, P. S. (2019). Eksistensi Industri Pis Bolong Sebagai Media Sosialisasi Religiusitas Budaya Bali Bagi Wisatawan Di Desa Kamasan, Klungkung. Majalah Ilmiah Widyacakra, 1(02).

Jayendra, P. S., Sudarmawan, I. W. E., \& Wijaya, N. S. (2019). Eksistensi Produk Pis Bolong Sebagai Media Edukasi Religiusitas Budaya Bali Bagi Wisatawan Di Desa Kamasan, Klungkung. Jurnal Ilmiah Hospitality Management, 9(2), 134-145.

Muljadi, A. J. (2009). Kepariwisataan dan Perjalanan. Jakarta: PT RajaGrafindo Persada.

Pantham, P. (2019). A-Na (d) tayaSati Hubungan Anapanasati (Nafas Buddha) di dalam Struktur Tari Klasik Thailand. JOGED: Jurnal Seni Tari, 10(1), 17-30.

Sukaatmadja, I. P. G., Wardana, M., Purbawangsa, I. B. A., \& Rahanatha, G. B. (2017). Pariwisata spiritual: Berbasis event-event upacara agama Hindu. Prosiding Seminar Nasional AIMI, 27-28.

Sutama, I. K. (2013). Pariwisata Spiritual di Bali dari Perspektif Stakeholders Pariwisata. Jurnal Perhotelan dan Pariwisata, 3(2), 1.

Wijoyo, H., \& Surya, J. (2017). Analisis penerapan Meditasi Samatha Bhavana di Masa covid-19 terhadap Kesehatan mental umat buddha vihara dharma loka pekanbaru. Sumber, 329.

Zulkifli, Z. (2016). Doktrin Kasih Dalam Tradisi Agama-Agama Besar: Antara Teori Dan Praktik. Ilmu Ushuluddin, 3(2), 189-200. 